"Holacracy and Obliquity: contingency management approaches in organizing companies"

\begin{tabular}{|c|c|}
\hline & Emil Velinov (D https://orcid.org/0000-0001-6073-1196 \\
\hline AUTHORS & $\begin{array}{l}\text { Vasko Vassilev } \\
\text { lgor Denisov }\end{array}$ \\
\hline ARTICLE INFO & $\begin{array}{l}\text { Emil Velinov, Vasko Vassilev and Igor Denisov (2018). Holacracy and Obliquity: } \\
\text { contingency management approaches in organizing companies. Problems and } \\
\text { Perspectives in Management, 16(1), 330-335. doi:10.21511/ppm.16(1).2018.32 }\end{array}$ \\
\hline DOI & http://dx.doi.org/10.21511/ppm.16(1).2018.32 \\
\hline RELEASED ON & Tuesday, 20 March 2018 \\
\hline RECEIVED ON & Wednesday, 11 October 2017 \\
\hline \multirow[t]{2}{*}{ ACCEPTED ON } & Friday, 02 February 2018 \\
\hline & $(c))$ EY-NC \\
\hline LICENSE & $\begin{array}{l}\text { This work is licensed under a Creative Commons Attribution-NonCommercial } 4.0 \\
\text { International License }\end{array}$ \\
\hline JOURNAL & "Problems and Perspectives in Management" \\
\hline ISSN PRINT & $1727-7051$ \\
\hline ISSN ONLINE & $1810-5467$ \\
\hline PUBLISHER & LLC “Consulting Publishing Company "Business Perspectives" \\
\hline FOUNDER & LLC "Consulting Publishing Company "Business Perspectives" \\
\hline
\end{tabular}

NUMBER OF REFERENCES

27
NUMBER OF FIGURES

0
ニニ:

NUMBER OF TABLES

3

(C) The author(s) 2023. This publication is an open access article. 


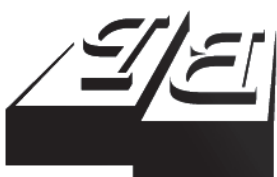

BUSINESS PERSPECTIVES

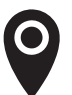

LLC "CPC "Business Perspectives" Hryhorii Skovoroda lane, 10, Sumy, 40022, Ukraine

www.businessperspectives.org

Received on: $11^{\text {th }}$ of October, 2017 Accepted on: $2^{\text {nd }}$ of February, 2018

(c) Emil Velinov, Vasko Vassilev, Igor Denisov, 2018

Emil Velinov, Ph.D., Assistant Professor, Riga International School of Economics and Business Administration (RISEBA), Riga, Latvia. Skoda Auto University, Department of Management and Marketing, Mlada Boleslav, Czech Republic.

Vasko Vassilev, Ph.D., Associated Professor, Department of Transport Management, University of Transport-Kableshkov in Sofia, Bulgaria.

Igor Denisov, Ph.D., Head of Department of Management Theory and Business Technologies, Institute of Management, Plekhanov Russian University of Economics, Russian Federation.

\section{(ㄷ)(1) $(9$}

This is an Open Access article, distributed under the terms of the Creative Commons Attribution-NonCommercial 4.0 International license, which permits re-use, distribution, and reproduction, provided the materials aren't used for commercial purposes and the original work is properly cited.

\title{
HOLACRACY AND OBLIQUITY: CONTINGENCY MANAGEMENT APPROACHES IN ORGANIZING COMPANIES
}

\begin{abstract}
The paper aims to examine the development of modern innovative management methods and practices such as Holacracy, Obliquity, Adhocracy and Sociocracy, which are novelty in the Management science and practice. The study illustrates contingency approaches in designing, managing and developing agile companies from wide varieties of industries. The paper sheds light on contemporary methods in organizing, planning and setting goals of companies in a post-knowledge era. It is like an operating system for business that requires the installation of different applications as applications for hiring employees, for setting salaries, for planning or logistics. In the paper, literature review on management innovations is conducted and subsequently statistical operationalization through STATA software has been employed to examine how particular organizations design and set up their organizational structures such as lean, agile or scrum. Paper results show that smaller companies are more agile and they tend to acquire Holacratic Management models thanks to the fact that self-managing teams exist internally and their organizational structures are flatter and more adaptive in comparison to the multinational corporations. Consequently, the paper concludes with suggestions on innovative management implementations for future development of companies and emphasizes the need for further research on what is the impact of Holacracy and Obliquity on shaping the organizational culture of companies.
\end{abstract}

\section{Keywords}

\section{JEL Classification M10, M15}

\section{INTRODUCTION}

In recent decades, the concept of the business environment in its broad sense has been radically changed. The globalization processes in the economy and the associated process of deregulation have led to the fact that the traditional foundations of the firm's benefits, such as privileged or unique access to financial capital, labor, land or markets, have declined in importance. In their place, a firm's ability to build, hone, upgrade, leverage, and extend specialized productive knowledge - so-called capabilities or competencies - is increasingly viewed as important, particularly those dynamic capabilities that allow a firm to modify its existing routines, procedures, or capabilities. The emerging organizational paradigm involves complementary changes in multiple dimensions. Recent research has shown that traditional management approaches are inadequate to cope with a hypercompetitive and fast changing environment (Rishipal, 2014). Each organization, which is willing to sustain in today's constantly changing competitive environment, must continuously seek for ways to improve its operations. In such a situation, it is necessary to focus on the rational use of all resources at the disposal of the company. Therefore, it is not imperial those firms that are largest or have the most resources that do best, but rather those that are smartest, see new opportunities, and develop new ways of doing business (Foss et al., 2012). 


\section{LITERATURE REVIEW}

\subsection{Management innovations}

Given that economies and organizations are becoming more and more complex, the environment is changing faster, and the acceptable response time is diminishing, the old management structures simply are not able to cope with changes and development. New methods and management systems require a complex, rapidly developing, virtual business environment of the present day. As economies and organizations are increasingly becoming complex, environment is changing more rapidly, and acceptable response time is diminishing, the old management structures are simply failing to cope with changes and development. The process that Darwin once referred to as "adaption to change" is very similar to a process, which is, in the context of rivalry between companies, considered as management innovation (Foss, 2012). Management innovation is about finding new, smarter, and more efficient ways of organizing activities in firms. Often, changes in the firm's environment, such as the introduction of new technologies or consumer trends, create opportunities for management innovation. In general, the most successful firms will be those that discover and seize new opportunities and then succeed in turning them into management innovations. This paper aims to examine the development of recent innovative management methods and practices and to address the structure of modern organizations in the context of a fundamental change in organizational structure. In the paper, various core benefits of innovative organization management are discussed and compared with other types of organizational structures. The importance of innovation and differences in management practices for organizational effectiveness is widely accepted (e.g., Janssen, Van De Vliert, \& West, 2004; Yuan \& Woodman, 2010) The findings in the management literature indicate that management innovations explain variations in productivity across firms and countries (Black \& Lynch, 2001; Cappelli \& Neumark, 2001). For example, there is a strong positive correlation between management practices and productivity (Bloom et al., 2010) or organizational structure and performance (Velinov \& Denisov, 2017). Some research indicates that establishments in better managed firms are sig- nificantly less energy intensive and there is a positive correlation between increased quality of management and total-factor productivity (Bloom, Genakos, Martin, \& Sadun, 2010). Therefore, the paper firstly provides the results of the research on different approaches and implementations of management innovations (such as methods which are denoted as Obliquity, Adhocracy, Sociocracy, self-management, etc.) in international organizations, including world practices and various techniques as examples.

\subsection{Holacracy, sociocracy and adhocracy}

The paper aims to aggregate practices of different companies of implementing recently emerged organizational framework called Holacracy, sociocracy and adhocracy as well as scientific literature studying this topic, to analyze them and to study the process of framework implementation, companies performance, to examine the positive and negative elements of this organizational structure, the problems arising along the implementation, and to ascertain why companies leave the structure (Gouveia, 2016). So, consequently, the study tries to draw a conclusion what is Holacracy, how it should be implemented, in which conditions (industries and optimal size of companies) it is best to be implemented (Schwaber, 2015). The study aims to aggregate practices of different companies, find common issues faced, and answer the following questions: What are the industries in which companies are expected to succeed with the current organizational structure? What is the optimal size of the company for this organizational structure? What are the most common problems companies face while implementing or practicing modern approaches in management?

\section{METHODOLOGY}

We have employed quantitative statistical models in order to critically examine previous research and answer the research questions stated by this paper, whereas we collected secondary data on the practices of 97 companies worldwide. The list of companies has been extracted from 'Structure and Process-Organizational Development' website (last updated June 14, 2017), along with the 
information about the industry, number of employees, years since foundation and Holacracy adoption.

The paper aims at investigating information on modern approaches of organizing across global companies, whereas the data have been collected based on previous research, books, articles, company reports, blogs, websites, or the case studies provided by companies themselves, advisory firms or consultants in management science and practices. Recent studies have found that it is difficult to find information about what time of organizational structure companies use unless they disclose this information on their websites or reports (Velinov \& Denisov, 2017). Moreover, the interest in a new organizational structure has rapidly expanded in last few years as the common problem the companies nowadays face is that if they decide to implement Holacracy (Georges, 2017). There is no structured analysis of practices and cases, so new adopters have to spend many hours looking for answers and examples (Knopka Company, 2014).

The findings of all relevant, high-quality individual studies addressing one or more research questions in form of scientific papers, books and articles as well as blogs and different conferences' notes, presentations and interviews with founders and CEOs of companies have been analyzed. The fundamental question in the field of strategic management is "Why are some firms successful - perhaps continually - while others are not?" (Foss, 2012). In this regard, the paper argues that more attention should be given to the role of organizational design and management processes to understand corporate success (Van De Kamp, 2014). The search for corporate success serves as the basis for organizational strategy. It is equivalent to the search for competitive advantage - the potential to earn above-average returns. In the management literature there is emerging discussion on the phenomena called "management innovations" (Birkinshaw, Hamel, \& Mol, 2015). In various management studies, there is a big discussion that academics and practitioners alike have emphasized innovations in products, services and processes but they have paid much less attention to management innovations as for example approaches in reorganizing and redesigning companies (Laloux, 2015).
Therefore, the purpose of our research is to consider sources of financial success and competitive advantages that, although not completely absent in strategic management, are based on the process of organization and management.

"It is not necessarily those firms that are largest or have the most resources that do best, but rather those that are smartest, those that see the new opportunities, and those that develop new ways of doing business" (Foss et al., 2012).

The process referred by Darwin to as "adaption to change" is analogical to what nowadays, in the context of competition between various companies, can be seen as "management innovation". Management innovation is about finding new, smarter, and more efficient ways of organizing activities in firms.

Management innovation practices can be portioned into three spheres of management innovations as defined by Nicolai J. Foss, Torben Pedersen, Jacob Pyndt, and Majken Schultz in their book "Innovating Organization and Management New Sources of Competitive Advantage" (2013): Changes in strategy (such as goal-setting), HRM (people management, incentive structures, and communications), and Changes in organization (organizational structures and delegation).

\section{RESULTS}

Based on the statistical operationalization of 97 companies which practice Holacracy, we can observe the following results.

\subsection{Holacracy by industry}

Table 1 shows that the majority of these companies belong to Consulting and Education industries (42.1\%): these are Management Consulting firms (17.89\%), Training/Coaching and Education (12.63\%), Startup Incubator, Co-working spaces and IT education (11.58\%). The second group of companies is connected to Information Technologies and Digital Marketing (27.37\%), among them are Digital, Hardware and Software systems (13.68\%), IT and Agile Web Development (6.32\%), Digital Marketing and Online/Offline 
Advertisement companies (7.37\%). It is Notable that significant number of companies with Holacracy are among Development, Aid and Nonp-rofit Organizations (7.37\%), such as Belgian company Durabilis (Investing in Base of the Pyramid Market) or Swiss organization Euforia (youth-driven social enterprise). Even companies providing Financial Services (4.21\%) show interest in Holacracy, for instance young Russian accounting company Knopka.

A few companies from Retail and Consumer Goods (3.16\%) and Telecommunications (2.11\%) are also present: among them are shoe-retailer Zappos from Las Vegas, and German Soulbottles (production of plastic-free, eco-bottles).

Table 1. Descriptive statistics of companies by industry

\begin{tabular}{l|c:c:c}
\hline \multicolumn{1}{c|}{ Industry } & Freg. & Percent & Cum. \\
\hline Development, Aid, Nonprofit & 7 & 7.37 & 7.37 \\
Digital Marketing and Adv. & 7 & 7.37 & 14.74 \\
\hdashline Financial Services & 4 & 4.21 & 18.95 \\
Hardware and software & 13 & 13.68 & 32.63 \\
systems, digital & 6 & 6.32 & 38.95 \\
IT, Agile Web Development & 6 & 11.58 & 50.53 \\
Incubator, Coworking and & 11 & 17.89 & 68.42 \\
IT Ed. & 17 & 17.89 \\
Management consulting & 13 & 13.68 & 82.11 \\
Other & 3 & 3.16 & 85.26 \\
Retail and Consumer Goods & 3 & 2.11 & 87.37 \\
Telecommunications & 2 & 12.63 & 100.00 \\
Training/Coaching/Education & 12 & 12.63 \\
Total & 95 & 100.00 & \\
\hline
\end{tabular}

Notes: Total number of observations $=97$, missing observations.

Among other companies (13.68\%) are: Tourism, Live sports, Eco-chemical company, Eco-shops and restaurants, Farming, Hospitality, Real Estate, Events Services, Oil \& Energy, Insurance, Online publishing, and Annual Conference.

\subsection{Holacracy by size of a company}

Table 2 shows the distribution of companies who applied Holacracy by number of employees, majority - more than 87 per cent are SME (small and medium sized enterprises with less than 250 employees - if Eurostat categorization is applied): among them there are $22.73 \%$ of micro enterprises and $45.45 \%$ - small companies.

Table 2. Distribution by number of employees

\begin{tabular}{l|c:c:c}
\hline Number of employees & Freg. & Percent & Cum. \\
\hline $1-10$ & 20 & 22.73 & 22.73 \\
\hdashline $11-50$ & 40 & 45.45 & 68.18 \\
\hline $51-200$ & 17 & 19.32 & 87.50 \\
\hline $201-500$ & 7 & 7.95 & 95.45 \\
\hline $501-1000$ & 2 & 2.27 & 97.73 \\
\hline $1001-5000$ & 2 & 2.27 & 100.00 \\
\hline Total & 88 & 100.00 & \\
\hline
\end{tabular}

Notes: $\mathrm{N}=97$, missing values $=9$.

Table 3 illustrates companies' lifespan using Holacratic model - when they have adopted Holacracy and how long they have been using Holacracy.

We can see that the companies wishing to use this organizational model are mostly young: the year of foundation is on average - 2004, while the 50th percentile is around 2007. Among outliers are the oldest companies, such as, for instance, David Allen Company (1920), Oliver Valves Nederland B.V. (1979), Kahler Financial Group (1981), and Scarabee Biocoop (1983-1984). The average number of years of implementation is 3.5, mostly because the companies have adopted Holacracy very recently (on average - in 2012), with outliers such as HolacracyOne (the inventor of Holacracy) and Diamond Media, who have been using Holacracy since 2007.

Table 3. Statistics on years

\begin{tabular}{|c|c|c|c|c|c|c|}
\hline Variable & Observations & Mean & Median & Std. dev. & Min & $\operatorname{Max}$ \\
\hline Year founded & 86 & 2004 & 2007 & 12.5 & 1920 & 2016 \\
\hline $\begin{array}{l}\text { Year of Holacracy implementation } \\
\text { beginning }\end{array}$ & 44 & 2012 & 2013 & 2.14 & 2007 & 2016 \\
\hline $\begin{array}{l}\text { Years of implementation (how long } \\
\text { Holacracy has been practiced) }\end{array}$ & 44 & 3.81 & 3.5 & 2.24 & 1 & 10 \\
\hline
\end{tabular}

Notes: $\mathrm{N}=97$, missing values $1=11$, missing values $2=53$. 


\section{CONCLUSION AND RECOMMENDATIONS}

The paper suggests that modern approaches in organizing such as Holacracy will work on a long-term basis, and the negative effects will be minimized if it is a micro or small-sized company (2-50 employees) whose internal informal and ad hoc communication is not capable to catch up with the growth of the organization. The ideal company is a young company with dynamic culture and self-driven employees who love their work, believe that their job has a better purpose (such as eco-productions, training/ coaching, or social or civic organizations) or it is a modern creative industry such as IT, software development or digital marketing and advertisement. Collective Wisdom defined by Birkinshaw is crucial for the company using Holacracy. And it is important to note that Holacracy is a good feature which is possible to implement in one team or smaller department which needs more agile approach or it can be a good experiment to test if Holacracy is suitable for your company. After all, we could add that the management model should be a conscious choice to suit the task at hand and the challenges you face and to enhance company distinctiveness.

In conclusion, we can state that no matter if Holacracy is chosen as an "operational system" or not, any of Management Innovation modern practices mentioned in this paper is worth noticing, since as once, supporting field of strategic management and organizational studies, which is called complexity theory, Apello in his book "Management 3.0" noticed: "Complexity thinking adds a new dimension to our existing vocabulary. It makes us realize that we should see our organizations as living systems, not as machines" (Apello, 2011). In other words, we would like our companies not just to work as mechanism which is ready to break due to a smallest mistake, but we want it to live, to be able to respond to changing environment and unpredictable problems. This can be compared to Machine Learning: we want our mechanism/company to work well, and if there is an unexpected problem it should not stop as any mechanical soulless creation would do, but solve the problem by itself by learning, changing, and adjusting.

At the same time, the old-school of management, the one we got used to and the one which in many cases we do not want to change, is the biggest obstacle to the adoption of flexible and learning structures around the world. In the future, it would be interesting to investigate what is the impact of Holacracy and Obliquity on organizational culture and organizational behavior across different companies and how these two management phenomena will evolve in the future across variety of industries.

\section{REFERENCES}

1. Appelo, J. (2011). Management 3.0 Leading Agile Developers, Developing Agile Leaders. Addison - Wesley.

2. Appelo, J. (2012). How to Change the World: Change Management 3.0. Rotterdam, The Netherlands: Jojo Ventures BV.

3. Bernstein, E., Bunch, J., Canner, N., \& Lee, M. (2016). Beyond the holacracy hype. Harvard Business Review, 2016 (July-August). Retrieved from www.scopus.com

4. Birkinshaw J., Ridderstråle J. (2015). Adhocracy for an agile age. McKinsey Quarterly.

5. Bloom, Nicholas, Christos Genakos, Ralf Martin, \&
Raffaella Sadun (2010). Modern Management: Good For The Environment or Just Hot Air? The Economic Journal, 120(544). Conference Papers (May 2010), 551-572.

6. Eckstein, J. (2004). Agile Software Development in the Large: Diving into the Deep. Dorset House, New York, NY

7. Foss, Nicolai J., Torben Pedersen, Jacob Pyndt, \& Majken Schultz (2012). Innovating Organization and Management New Sources of Competitive Advantage. Cambridge, UK: Cambridge University Press.
8. Gelles, D. (2015). At Zappos, pushing shoes and a vision. New York Times, 136.

9. Georges Romme (2017). Management as a science-based profession: a grand societal challenge, Management Research Review, 40(1), 5-9.

10. Gouveia, L. B. (2016). Holacracy as an alternative to organisations governance.

11. Graham, E. (2010). Supporting social movements: Facilitating deeper collaboration and social transformation through integral organizational practice and holacracy. Journal of Integral 
Theory and Practice, 5(1), 127-141. Retrieved from www.scopus.com

12. Greenfield, R. (2016). Why is it so hard to change how we manage ourselves? Retrieved from Montreal Gazette; Montreal, Que.: Retrieved from https://searchproquest-com.zdroje.vse.cz/docvie w/1775911216/8CB07B61DE84E0 $\mathrm{EPQ} / 9$ ? accountid=17203

13. Hamel, G. (2011). First, Let's Fire All the Managers. Harvard Business Review, 89(12), 48-60.

14. Heintel, P., \& Krainz, E. (2015). Projektmanagement: Hierarchiekrise, Systemabwehr, Komplexitätsbewältigung (6 Aufl.). Wiesbaden: Gabler.

15. Holacracy Constitution (2015, June). Holacracy Constitution v4.1. Retrieved from http://www. holacracy.org/constitution

16. HolacracyOne, LLC (2015). Holacracy Constitution v4.1. Retrieved from http://www.holacracy.org/constitution

17. HolacracyOne (2013). David Allen Company.
18. Knopka Company (2014, October 23). Что такое холакратия и почему она вам не нужна [Chto takoe kholakratiya i pochemu ona vam ne nuzhna]. Retrieved from https://habrahabr.ru/company/ knopka/blog/241327/

19. Laloux, F., \& Wilber, K. (2014). Reinventing Organizations: A Guide to Creating Organizations Inspired by the Next Stage of Human Consciousness. Nelson Parker.

20. Lines, M., Scott, W., \& Ambler, S. W. (2015). Introduction to Disciplined Agile Delivery: A Small Agile Team's Journey from Scrum to Continuous Delivery. CreateSpace Indep. Publishing.

21. Mint (2016, June 14). Holacracy, managerless offices and the future of work. Retrieved from New Delhi https://search-proquest com. zdroje.vse.cz/docview/1796053443 /8CB07B61DE84E0EPQ/17?accou ntid $=17203$

22. Rishipal (2014). Analytical Comparison of Flat and Vertical Organizational Structures. European Journal of Business and Management, 6(36), 56-66. Retrieved from www.iiste.org

23. Robertson, B. J. (2014). Holacracy: The New Management System for a Rapidly Changing World. Henry Holt \& Co.

24. Schwaber, K. (2015). Nexus Guide. The Definitive Guide to Nexus: The exoskeleton of scaled Scrum development. Retrieved from https://www.scrum.org/Portals/0/ NexusGuide\%20v1.1.pdf

25. Simon, H. A. (1967). The business school: a problem in organizational design. Journal of Management Studies, 4(1), 1-16.

26. Van De Kamp, P. (2014). Holacracy - A radical approach to organizational design. Elements of the Software Development Process-Influences on Project Success and Failure. University of Amsterdam, 13-26.

27. Velinov, E., \& Denisov, I. (2017). The Relationship between Contemporary Holacratic Models of Management. GATR Global Journal of Business and Social Science Review, 5(2), 10-16. 